\section{Response to: 'Knee osteoarthritis and bisphosphonates: Could BCP crystals be the missing link?' by Murphy et al}

I read with great interest the letter from Murphy and $\mathrm{McCa}-$ rthy ${ }^{1}$ : 'knee osteoarthritis and bisphosphonates: could BCP crystals be the missing link?'. ${ }^{1}$

I recently gave comments on two case-control studies, ${ }^{2}$ in which the need for a total knee prosthesis was around 25\% lower in bisphosphonate (BP) users than in controls. ${ }^{3}{ }^{4}$ What could be the explanation? It could be related to epidemiology: BP-users have a healthier lifestyle than non-users, by doing more exercise therapy, preventing overweight and so on. The other option is a biological effect, for example, an effect of BPs on the underlying subchondral bone in patients with osteoarthritis (OA). ${ }^{5}$

Murphy and McCarthy bring in that BPs have a strong affinity for basic crystal phosphates (BCPs) and that this might inhibit inflammatory reactions in the synovial fluid. ${ }^{1}$ They argued that BCPs have been found in the cartilage of $100 \%$ of patients with OA at the time of joint replacement and that BCPs might contribute to inflammation in OA.

Although this is certainly a valuable suggestion, the incidence of clinically manifest knee-osteoarthritis based on BCP-crystals is low in patients with OA. Since knee-OA is a whole joint disease, cartilage, bone, synovial inflammation and muscular weakness all play a role, ${ }^{6}$ it is very likely that other factors are among the mean determinants of inflammation and pain in patients with knee-OA. So, BCP-crystals are probably not 'the' missing link, but might be a' missing link.

Nevertheless, since the pathogenesis of OA is not fully elucidated and therapeutic options are scarce, further research in the direction of BCPs and BPs in patients with knee-OA is very welcome.

Willem Lems
Correspondence to Willem Lems, Department of Rheumatology, VU University Medical Center, Amsterdam 1007MB, The Netherlands; wf.lems@vumc.nl

Handling editor Josef S Smolen

Funding The authors have not declared a specific grant for this research from any funding agency in the public, commercial or not-for-profit sectors.

Competing interests None declared.

Patient consent Not required.

Provenance and peer review Commissioned; internally peer reviewed.

(c) Author(s) (or their employer(s)) 2019. No commercial re-use. See rights and permissions. Published by BMJ.

\section{A) Check for updates}

To cite Lems W. Ann Rheum Dis 2019;78:e142.

Received 12 October 2018

Accepted 13 October 2018

Published Online First 2 November 2018

\section{S Linked}

http://dx.doi.org/10.1136/annrheumdis-2018-214421

Ann Rheum Dis 2019;78:e142. doi:10.1136/annrheumdis-2018-214493

\section{REFERENCES}

1 Murphy CM, McCarthy G. Knee osteoarthritis and bisphosphonates: could BCP crystals be the missing link? Ann Rheum Dis 2019;78:e141.

2 Lems WF. Bisphosphonates: a therapeutic option for knee osteoarthritis? Ann Rheum Dis 2018;77:1247-8.

3 Neogi T, Li S, Peloquin C, et al. Effect of bisphosphonates on knee replacement surgery. Ann Rheum Dis 2018;77:92-7.

4 Fu SH, Wang CY, Yang RS, et al. Bisphosphonate use and the risk of undergoing total knee arthroplasty in osteoporotic patients with osteoarthritis: a nationwide cohort study in taiwan. J Bone Joint Surg Am 2017;99:838-46.

5 Roman-Blas JA, Castañeda S, Largo R, et al. An OA phenotype may obtain major benefit from bone-acting agents. Semin Arthritis Rheum 2014;43:421-8.

6 Bijlsma JW, Berenbaum F, Lafeber FP. Osteoarthritis: an update with relevance for clinical practice. Lancet 2011;377:2115-26. 